\title{
FACILITATIVE PROJECT MANAGEMENT: CONSTRUCTING A MODEL FOR INTEGRATED CHANGE IMPLEMENTATION BY UTILIZING CASE STUDIES
}

\author{
VERONICA HODGSON \\ J ZAAIMAN \\ Programme in Leadership in Performance and Change \\ Dept of Human Resource Management \\ Rand Afrikaans University
}

\begin{abstract}
Change management theory is extensive, and organisations constantly adapt to and embrace change. In post-apartheid South Africa we are building a racially integrated business environment and society, and leverage its competitive re-entry into the world business arena. Research to date has found that the majority of change initiatives fail due to resistance caused by poor conceptualisation and planning, and the lack of proper integration of the people and business dimensions of change. The model to implement a successful change program will be designed using a combination of readily available skills and techniques. Its development and testing will take place within the context of three case studies.
\end{abstract}

\section{OPSOMMING}

Die teorie van veranderingsbestuur is omvattend. Organisasies moet op konstante wyse daarby aanpas en dit integreer. In Post-Apartheid Suid-Afrika bou ons tans 'n ras geïntegreerde besigheidsomgewing en gemeenskap, en benut dit maksimaal in ons toetrede tot die mededingende wêreld besigheidsarena. Huidige navorsing het bevind dat die meeste veranderingsinitiatiewe faal weens weerstand teen verandering wat deur swak konseptualisering en beplanning, en 'n gebrek aan behoorlike integrering van mense en die besigheidsdimensies van verandering veroorsaak is. Die model om 'n suksesvolle veranderingsprogram te implementeer, sal ontwerp word met geredelik beskikbare vaardighede en tegnieke. Die ontwikkeling en toetsing sal binne die konteks van drie gevallestudies plaasvind.

Over the years Hodgson has read many articles and studied theories pertaining to organisational change, and has been impressed by the extent of theoretical information available. Of particular interest has been information regarding the implementation of change, which often follows strategic and organisational analysis.

In practice, research has shown that the majority of change initiatives fail. (Kotter, 1996; Barrezeele, 2001; Ashkenas \& Francis, 2000; Duck, 1993; Strebel, 1996).

Change theorists, such as Kanter (1989); Johnson \& Scholes (1997); Hannagan (1995); \& Thompson (1997); to name but a few, concur that in order for change to be successfully implemented, it is essential to gain people's buy-in to, and ownership of, the change.

In her search of the literature, Hodgson found little in terms of practical insights about how this is best done, and how to integrate business change requirements and human change issues across the organisation(s). For example, broader more theoretical approaches are offered by theorists such as Pettigrew and Whipp (as cited in Johnson \& Scholes, 1997), Peters (1990) and Senge (1999). Other approaches focussed specific areas within change (e.g. the fostering of team commitment), such as those offered by practitioners Hudson (2001), Ashkenas and Francis (2000).

Texts mostly discussed what should be done - such as Lewin's change model (Johnson \& Scholes, 1997) of "Unfreeze, Transition, Refreeze", Price Waterhouse's change principles (1996), or indeed Central Computers and Telecommunications Agency's PRINCE2 project management methodology (2000). They did not specifically advise how to go about doing it.

The study therefore seeks to develop and test (within a series of case studies) a practical model for integrating these aspects and setting out a generic approach for achieving the theoretical ideals of change management, in practice.

Requests for copies should be addressed to: V Hodgson, Department of Human Resource Management, RAU University, PO Box 524, Auckland Park, 2006
For the purposes of this work, the terms systematic and interactive change dimensions will be used. The systematic dimension refers to the business aspect of change, which is about a logical, structured approach to revising the "mechanics" of the business. The people dimension of change is about changing attitudes, easing fears, and building co-operation, it is about creating interaction, communication and building trust. Since this is a "social aspect" of change, which has at its core interaction, relationships and leadership, it will be termed the interactive dimension of change.

The objectives of the research were:

- To capture the challenges faced by organisations in integrating the systematic aspects of change management (such as system design) and the softer interactive issues (empowerment, buyin). This would be achieved through a literature review of relevant change issues, and supported by case studies, which reflect the issues and how they were overcome.

- To develop the Facilitative Project Management Model for Integrated Change, which may be offered as an approach for integrating the systematic and interactive aspects of organisational change. The model will be based on the outputs of a further search of theories, concepts and literature and will be developed and tested within the case studies

Key to the study are exploratory, semi-structured interviews and informal discussions which will mirror the structured project progress meetings, to develop an understanding of how people think and feel about topics of concern to the research (Oppenheim, 1992).

\section{Change Issues}

The business world has become dynamic, unpredictable and turbulent, requiring a company to continuously change to meet the demands of the competitive environment. Thus, change has become the norm in business, and the management of change needs to be designed into the daily life of an organisation and embraced by those within it (Deal \& Kennedy, 2000; Thompson, 1997; Johnson \& Scholes, 1997; Hannagan 1995; Ansoff \& McDowell, 1990; Peters, 1990; Woodward \& Buchholz, 1987; Kanter, 1983). 
Despite this, it is of concern that so many such initiatives fail, due mainly to a lack of understanding of how the change is to be approached (conceptualisation and planning) and change resistance (Barrezeele, 2001; Ashkenas \& Francis, 2000; Sull, 1999; Kotter, 1996; Strebel 1996; Duck 1993).

Steiner (2001) and Duck (1993) state that the traditional (mechanistic) model of managing change is unrealistic and doesn't work. Under this model the initiative is broken into small pieces, each of which is managed along operational lines as a series of individual projects (as noted by Kotter, 1996 \& Peters, 1990), which are often uncoordinated with one another.

The key is to manage or oversee the change dynamic, not its individual pieces (or projects), and taking a holistic approach, which treats the systematic (business) and interactive (people) aspects of change as a sum of its parts (Prosci, 2000; Mintzberg et al, 1998; Duck, 1993). Overlooking the human aspect of change leads to resistance to the work that is being undertaken, and increases the change of failure. This theme appears in the works of numerous change theorists and practitioners, such as Johnson and Scholes (1997); Thompson (1997); Tracey (ed.) (1994); Woodward and Buchholz (1987); Kanter, (1983).

\section{Change Resistance}

The central focus of change must be on its impact on people as the real issues of change are emotional, not strategic or technical ones. People need to have some sense of security when facing change. By including them in the planning and conceptualisation of change, and affording them the freedom to express their ideas and contribute, the threat to personal security, relationships and status are lessened as a sense of stability and control over their destiny is developed. Resistance and organisational inertia is thereby overcome, and change momentum is built (Macri, Tagliaventia, \& Bertolotti' 2000; Deal \& Kennedy, 2000; Schalk, Campbell \& Freese 1998; David, 1997; Johnson \& Scholes' 1997; Robbins, 1997; Strebel, 1996; Hannagan, 1995; Woodward \& Buchholz, 1987). A paradox is formed - for success, change (which is an unstable event) needs to occur in an environment of stability (Price Waterhouse, 1996).

Addressing this paradox forms part of the work of the change management model that this study develops, and will be addressed later in the study.

The main barriers to the successful implementation of change include:

- Lack of order, through an ill-conceived conceptualisation of the need to change, or an unplanned, uncoordinated approach to holistic change management, which impacts business continuity. This could be due to a lack of knowledge about how to go about implementing change in practice.

- Change resistance (consisting of resentment, lack of common understanding, and insecurity among other things) is usually caused by poor information dissemination and ineffective or incomplete communication methods, as well as a lack of involvement of, or attention to, the needs of affected stakeholders. This may in some cases be linked to the point above.

The question is how to overcome these issues in practice. According to Mintzberg, Ahlstrand and Lampel (1998) there is an overwhelming amount of literature about the practice of implementing change, but there is no consensus as to what works best. There appears to be a divergence between the cerebral or theoretical approach to change and the practical approaches generated by those who have led change. The theoretical approaches appear to offer a "what" rather then a "how" approach and those offering practical guidance appear to offer only specific advice within the context of their organisation, personal experience or field of specialisation. Their work usually focuses on the human experience of change, and how challenges were overcome. Examples of such works are those by Munck (2001) Levy (2001) Hudson (2001) Bernick (2001) Charan (2001).

These approaches should be two sides of the same coin, but can lack interactive linkage. Theory ought to be fully translatable into practical, tactical steps for change, and vice versa.

\section{Existing Change Methods and Approaches}

There are many approaches to, and methods of change, which vary from the theoretical to the specific (where a change model will target an individual area of change such as business process re-engineering or systems change). Examples of broader or more theoretical change implementation advice offered by wellknown theorists and institutions include

a) Tom Peters' five areas of management which create proactive performance (1990).

b) Price Waterhouse's (1996) - fifteen rules for managing the complexities of change.

c) Kotter's eight steps to organisational transformation (1996).

d) Pettigrew and Whipp's five characteristics of organisations which manage change successfully (as cited in Johnson \& Scholes, 1997).

e) Senge's five practices for building change capability (as cited in Senge, Roberts, Ross, Smith, Roth \& Kleiner, 1999).

These all appear to explain the "what" of change management, but offer little in terms of a process for the "how" - the practical implementation thereof.

Mintzberg captured the different types of change methods available in his work on change methodologies, a copy of which is shown in figure 1 below (as cited in Mintzberg, Ahlstrand, Lampel, 1998).

What this highlights is that in major organisational change, several different methods or projects will form elements of the overall change work, and will probably occur at the same time. They must be planned, co-ordinated and controlled to maintain order and achieve a seamless transition, with minimal disruption to daily operations and profitability, and must occur as quickly as possible if the outcome is to be relevant to the business aims and environment (Price Waterhouse, 1996). A lack of co-ordination across work streams, disciplines and departments could lead to disruption, errors, crisis management and a poorly implemented change effort (Duck, 1993). With all this to balance, Mintzberg, et al (1998) statement regarding change approaches is appropriate: "this is a confusing body of work."

Based upon the literature, Hodgson wished to view the change management issues in practice, in an African context to see whether mainly first world texts apply in a change situation in the third world. If so, it was intended that lessons learned from the first case study will lead to the development of a model that addressed these matters, and would be tested in following case studies.

\section{Case Study 1 - Innscor Distribution Zimbabwe}

This case study could arguably be termed a typical example of change management in practice. No change management methodology or theory was used to implement the change, and no intervention on the part of Hodgson was attempted. The main purpose of this work was to document the change events as they occurred, and to assess whether these events are representative of the change issues or pitfalls discussed in this section.

The change centred on the merger of Zimbabwe Photo Marketing (ZPM) and Zimbabwe Wholesale Distributors (ZWD). ZPM and ZWD import, stock, market, sell and distribute 


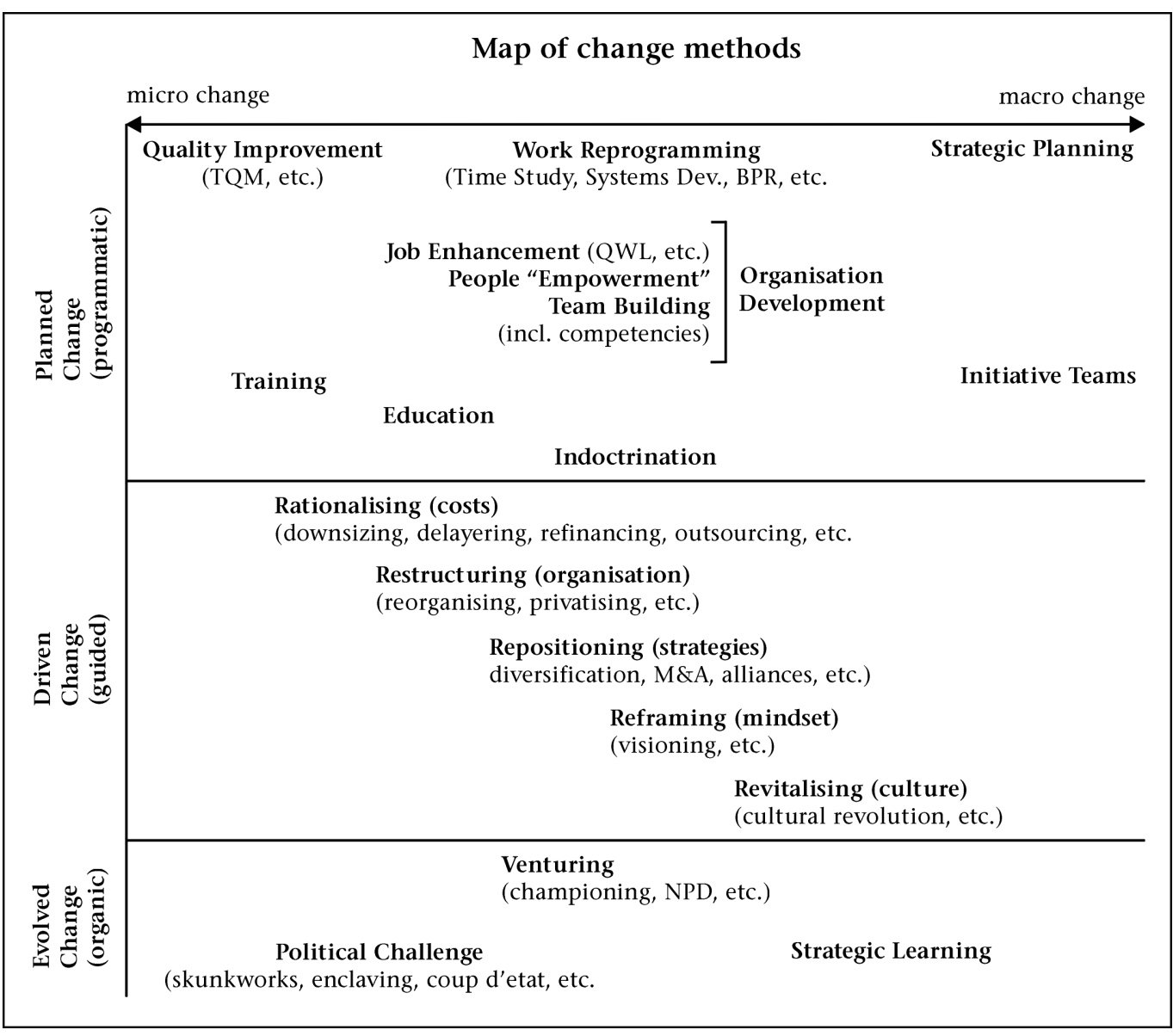

Figure 1: Map of change methods

(c) Henry Mintzberg, August 1997

premium products under exclusive territorial distributorship agreements with foreign suppliers. The Group Head Office wished to embark upon regional expansion, as worsening economic conditions in Zimbabwe indicated that the future survival of the group could only be assured if it were successful in more stable countries in the region.

It was noted that there were synergies and operational duplications between ZPM and ZWD, which if they were merged could better support the regional expansion.

Many of the issues, which arose in the merger were a result of a lack of proper planning, or conceptualisation of what the inherent difficulties of the merger were from a process point of view. The approach to implementing the merger was uncoordinated (resulting in problems such as the delays in order processing and delivery because of poorly timed system integration). The change was driven by the managers, without proper attention to communications among themselves or between them and the staff. This led to misunderstandings, rumours and continuous crisis management, which impacted on customer service and organisational profitability. It resulted in a far longer and more costly implementation than intended. Overall, the human experience of the change was poor, characterised by fear, frustration, conflict and isolation.

The study showed that both the managers and the staff felt they would have benefited from a more structured approach. This included having a sense of knowing what was involved in the merger, understanding the implications of changing the systems and making allowances for those implications, as well as having a more detailed and considered plan to follow.

Discussions also revealed that closer involvement of the staff in the change itself via more open (and less hostile or paternalistic) communications would not only have alleviated the pressure on management to drive the change, but would have given the staff a sense of ownership and control over events. This would have assisted in stabilising the culture and led to greater knowledge and effort contributions to the work of the merger.

In summary, then, it appeared that the issues experienced were representative of the type of change pitfalls discussed in the change management literature review. The change had not been carefully conceptualised, the systematic and interactive aspects were not integrated, and the human experience of the change was poor, and problematic.

The first version of the Facilitative Project Management Model for Integrated Change Implementation was built to address the issues highlighted in the literature review and demonstrated in Case Study 1, by providing a combination of participative, consensus planning to define what needed to be done to achieve an agreed objective.

Building the Facilitative Project Management Model for Integrated Change Implementation

Organisations consist of people. People drive all areas of the business, internally and externally, to ensure its competitiveness and survival. The complexity of an organisation lies in the interactions of its systems, processes, information flows and people. It is a finely tuned organism, and any changes to any part of it should take into account the need to maintain a balance between its parts.

This implies a deliberate, and well considered approach needs to be taken, not only to ensure effective implementation of a change, but also to ensure that it delivers intended business benefits, while at the same time minimising disruption to clients and staff. 
Any process, or model for implementation that intends to offer an integrated, holistic approach to change, should ideally be based in generic (readily available) methods. It should be applicable to any type of change, across all types of organisations. The point is to provide a comprehensive, practical process, which maximises the efficiency of the work of implementing the change, minimises the business/operational impact (continuity) and provides the security and commitment-building of a "no surprises" environment in the midst of uncertainty.

The need to foster collaborative interaction, and for a structured "no surprises" approach to the uncertainties of change, are central to the disciplines of Facilitation and Project Management.

Project management - definitions and knowledge areas Project management is a method, which combines planning, directing and controlling of resources, through a well-managed set of activities to achieve a unique and pre-defined outcome within an agreed time frame, budget and performance standard. (Int'Veld, 2000; Central Computers \& Telecommunications Agency, 2000; Project Management Institute, 1996).

Project management was initially applied to the construction industry and later to the IT industry, but is increasingly being recognised as having a place in wider business initiatives (Kloppenborg \& Opfer, 2002). It is designed to provide an organisation and controlled method for developing a new product or desired outcome, whilst balancing competing demands, which include:

- The scope, time, cost and quality of a venture.

- Managing stakeholders with differing needs and expectations.

Its structured approach aids early warning of risks or problems, and is designed to deliver a co-ordinated, "no surprises" route to completion. Projects will have a defined start and end date, and provided that control is maintained over the content, scope, quality and timing of the work, it will come to a clear end and not drift on longer than required.

The management of competing demands and delivering unique products or outcomes forms some of the key aspects of implementing a change initiative. It is for this reason that the writer wishes to examine the application of the project management structures and disciplines as part of the practical model for change implementation.

The point of project management is to keep the work of the project aligned with the business strategy in order to delivery the expected business benefits, and has embedded in it systems and tools for doing just that. It is supported by a business case, against which the project is tested during its implementation to ensure that its deliverables are aligned with the intended business outcomes, within predetermined tolerance and quality levels. The diagram in Figure 2 below illustrates this.

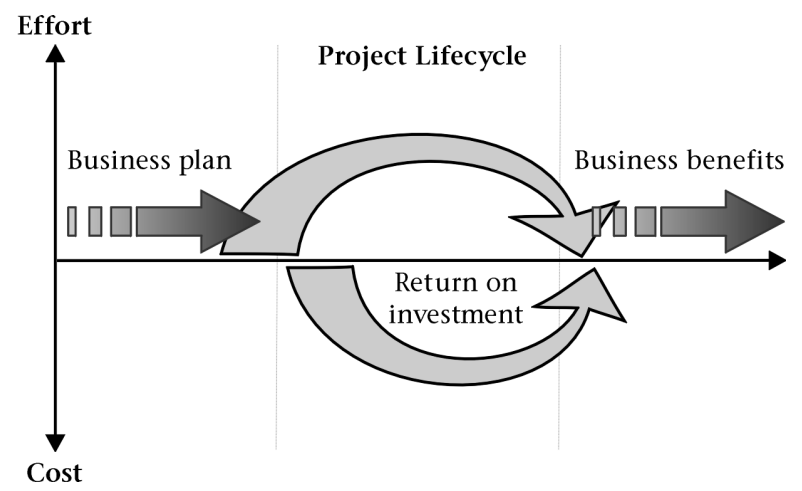

Figure 2: Delivering business benefits, balancing cost and effort

Courtesy of the X-Pert Group
Whilst project management takes into account team building, and teamwork, it relies upon the project manager to lead the interactions, build the team, lead the change, manage stakeholders and overcome resistance. There are also the structures and controls which need to be managed - project risk management, contingency planning, leading and directing team efforts, progress monitoring, reporting, controls mechanisms, auditing and so on.

This places an enormous responsibility upon the shoulders of one person, who may or may not be supported by an administrator. As discussed by Verma (1997), the project manager is seen as the change champion, creating support for, and buy-in to the change not only within the project team, but also across the organisation itself. Since up to $50 \%$ of a project manager's time is taken up by the documentary aspect of the methodology, which leaves little time to fully integrate people issues from those outside of the project team. This is a potential weakness within project management as a change methodology.

\section{Facilitation}

We then considered the benefits of facilitation, which could be the "glue" to building the communication and trust that is essential to overcoming resistance. It would aid in embedding project management principles, and foster knowledge sharing and buy-in, which would ease the burden of responsibility for championing change from the shoulders of the project manager.

An intrinsic part of projects and organisational change initiatives is that they are about building something new, unique or innovative, which requires the active participation and commitment of people. Here, facilitation is key as its techniques and philosophy is about building group co-operation, participation and creativity.

The Facilitator creates an environment that encourages open communications, fosters empowerment and the in-depth consideration of cumulative insights, builds group co-operation, and aids them in achieving consensus and mutual commitment to common goals (Stanfield, 2001; Bacal, 1998; Epps, 1998; Rough, 1997; Kanter, 1989; Ettlie \& O'Keefe, 1982).

Facilitation could therefore aid the transition to a new type of working, support the processes of project management, and assist the successful implementation of change by integrating the systematic and interactive aspects of change. If such an approach or model were fully embedded in the organisation it could remain as a fundamental process for embracing ongoing change requirements, as alluded to by change theorists. This is demonstrated in Figure 3 below.

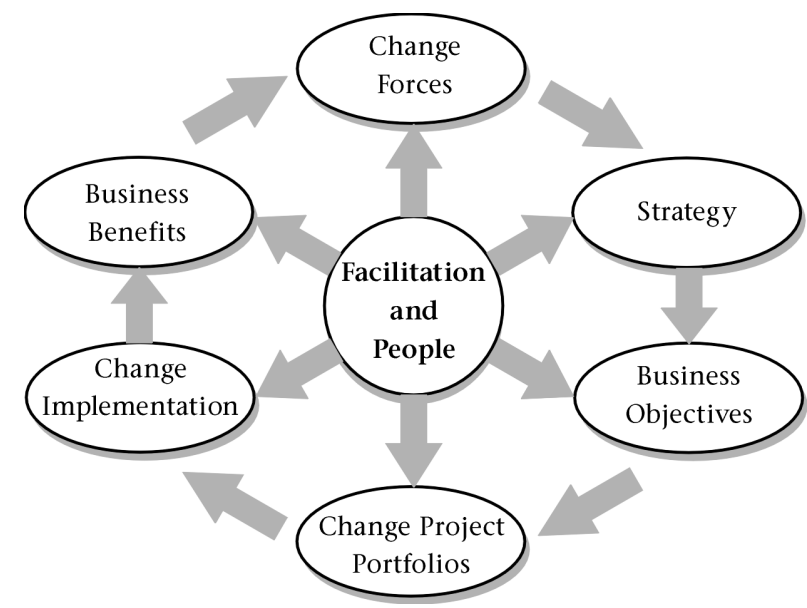

Figure 3: Embedding integrated change 
The combined approaches of project management and facilitation could pull together the various pieces of change work underway in an organisation (e.g. business process reengineering, organisational design, supply chain management, IT systems design etc) and knowledge, disciplines and efforts of each of the departments involved.

The resulting model lends itself to integrating not only the two dimensions of each change project, but also to the integration of each of the change project into a holistic portfolio of organisational transformation. This multi-dimensional integration crosses departments, disciplines and functions and achieves alignment with the overall strategic objective and business benefits in an efficient manner.

The model, named the Facilitative Project Management for Change Implementation, is shown below in Figure 4. Within this model, Hobson has planned certain tactical procedures, which are noted below in Figure 4, and demonstrates in more detail how the systematic and interactive aspects of change are intended to be integrated in her approach to the following case study.

Based on the outcomes of the first case study, it seemed to Hodgson that a facilitative approach, underpinned by structured planning could be key to holistic, co-ordinated organisational change. This led to the exploration of the concepts within project management and facilitation (as discussed above), which were adapted and combined to form the first version of the Facilitative Project Management Model for Integrated Change Implementation.

The testing and revision of the model took place within two major change initiatives that occurred in two large South African organisations. The lessons learned from the application of the model in each study are noted below.

\section{Case Study 2 - Pick 'n Pay South Africa}

The purpose of this case study was to test the first iteration of the Facilitative Project Management model, and to use the learnings generated at the end of the study to refine the model.

The case study centred on Pick 'n Pay, a leading supermarket chain in South Africa. As part of the ongoing drive by the organisation to turn shopping into a pleasant and convenient experience for its client, it was decided to expand into the field of e-commerce and set up an Internet Shopping web-site and home delivery service, with call centres for telephone and fax orders. The venture was branded Pick 'n Pay Home Shopping. The driving force was that people have less leisure time, and would prefer to be free to spend that leisure time doing things other than shopping in store.

The project's objective was to set up 13 stores with the capability to fulfil Home Shopping orders. The capability included special in-store systems enabling it to receive orders, dedicated grocery "pickers" to select and scan the ordered items, and full delivery services (using a contracted transport company).

From the outset, the facilitative project management model for change was applied, using the facilitative and project management techniques set out within it. Discussions at the close of project revealed that the structured and prioritised approach aided the transition.

The outcomes of the study showed that having a plan which had been developed by those who were going to do the work, was key to making the unknown, known. When things were not going according to plan, it was easy to make revised completion date estimates, or to implement action plans to make up time, knowing how it would affect the overall project completion date, or affect the work of the other projects.

The attention to planning, progress monitoring, interdependencies and implications of changing circumstances, tasks, times, and resources enabled a structured approach to delivering the work in an ordered way.

The facilitative techniques helped to smooth conflict and build a cohesive team, who were able to debate and resolve issues with little conflict and full participation. Emotional issues were drawn out and managed, sources of resistance were identified and overcome through objective discussion, and communication lines were actively built and maintained.

The model in its first version aided the delivery of the change, but needed to be refined. This included adjustment to the facilitative techniques used within each stage of the project

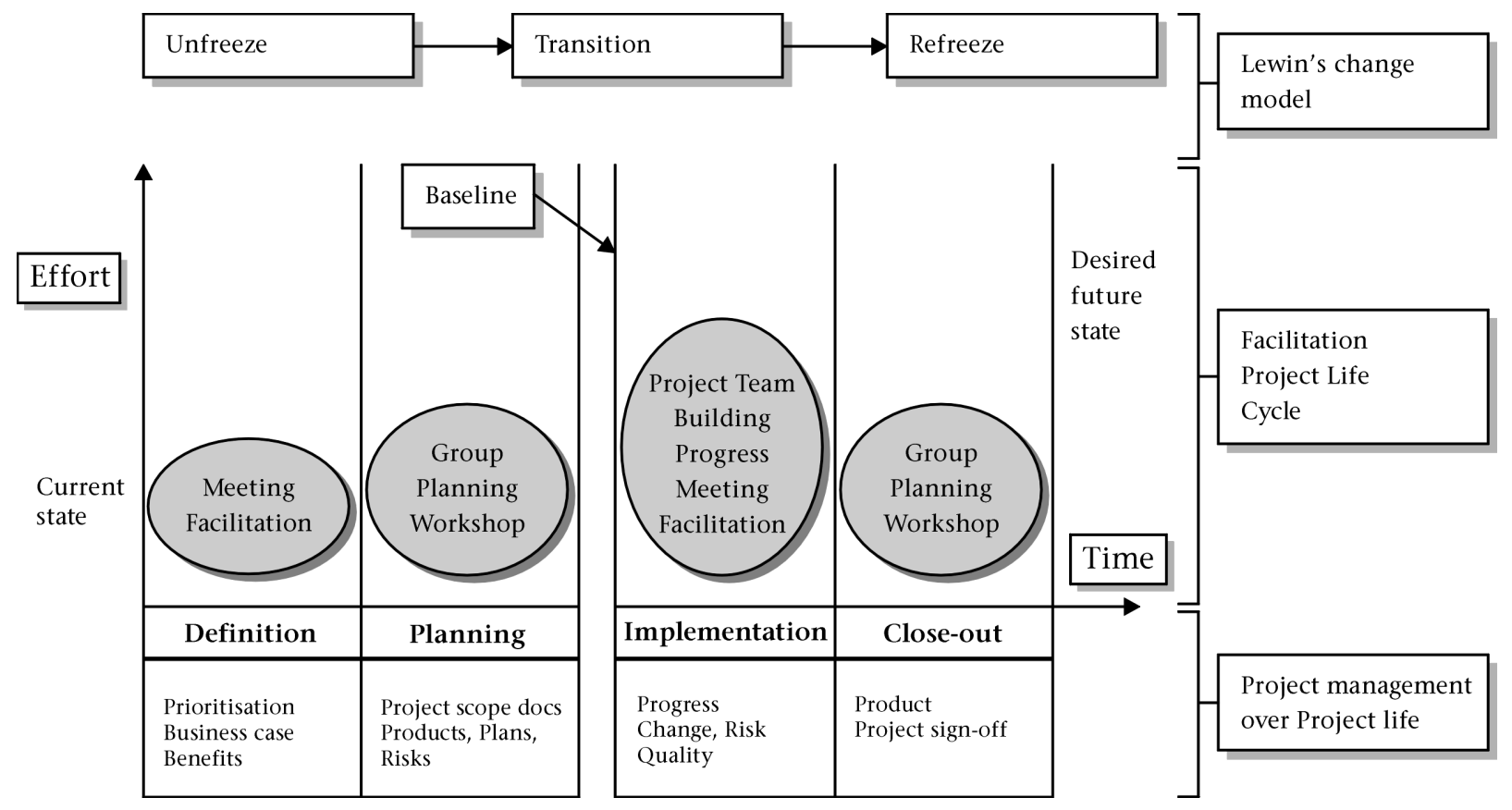

Figure 4: Integrating facilitation skills with project management phases to combine systematic and interactive aspects of change Facilitative project management model version 1 
life cycle and the introduction of more formal project management control mechanisms (such as active risk management, and change control).

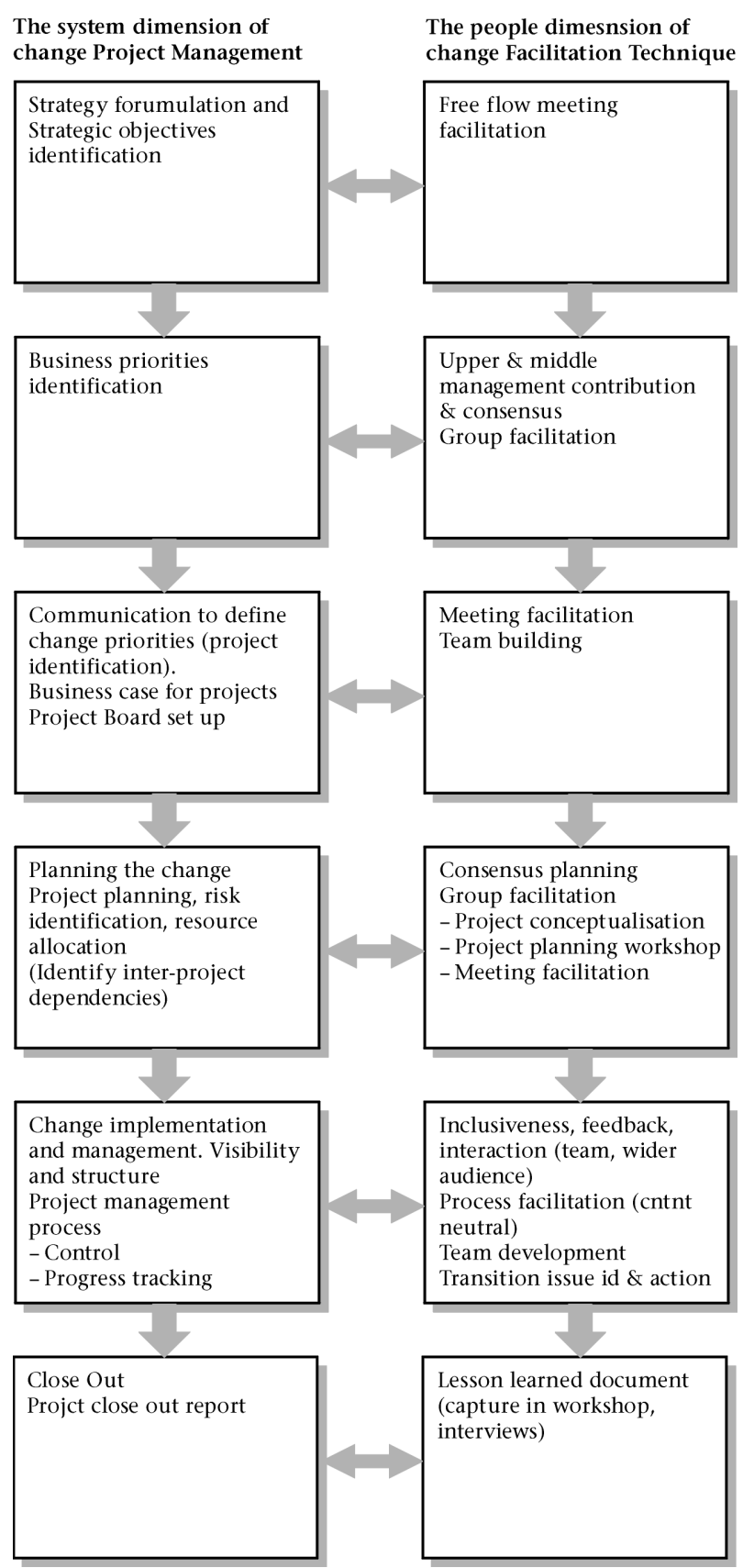

Figure 5: The facilitative project mangement model for integrated change implementation version 1 Tactical procedures

The concept of phasing out the involvement of the neutral project facilitator was introduced, as the techniques of project management and facilitation became embedded in the project teams and stakeholders. This was to help ensure that the concepts were taken on as part of the organisation culture, and not remain linked to the neutral project facilitator.

\section{The Revised Facilitative Project Management Model for Integrated Change Implementation}

The refinements were made and version two of the facilitative project management model (shown below as Figures $6 \& 7$ ) and was tested in the third and final case study.
As can be seen from the Facilitative Project Management Model Version 2 above the focus of neutral facilitation alters during the different stages during the implementation of the change, so that it is appropriate to the people requirements of each stage. This is to enable the facilitative "stamp" to be placed on the work of the change at all times, so it permeates through the team and out to the affected stakeholders, creating a dynamic feedback and participatory cycle necessary to foster knowledge sharing and overcoming change resistance.

\section{Case Study 3 - Merger of two Investment Banks}

This case study centred on the merger of two high-profile organisations in the finance sector, which had two very different cultures, systems and business processes. The revised Facilitative Project Management Model (Version 2) was applied to encourage buy-in and assist the members of the two organisations in the planning and implementing of their merger in a structured yet participative way, and will serve as a final test for the model.

The first organisation (which will be referred to as Company A), is an independent, international investment banking group that provides a specialised range of asset management products and services to selected clients. Company A has branches in Sandton, Cape Town, Durban, London, Guernsey, and Dublin. It is one of the 20 largest companies listed on the Johannesburg Stock Exchange with a market capitalisation on a fully converted basis at 31 March 2001, of R18.9bn (US\$2.3bn). In 2000, Company A bought a competing investment bank (which will be referred to as Company B) as part of its drive to gain further market share. Company B's physical and financial assets, valued at approximately R 6 billion, were to be integrated into Company A.

It was clear from the outset that the merger would be an extremely complex initiative, affecting all levels of both organisations and ongoing shareholder value. This initiative was made more difficult due to the fact that the merger had to be complete before the Capital Gains Tax compliance legislation act came into being. Added to this was the reliance upon a shrinking pool of staff whose tacit knowledge and expertise in their organisations were critical to the success of the merger, and who could only attend to the merger part-time, over and above their day-to-day operational jobs and involvement in other projects.

Success relied upon the development of cross-functional and inter-organisation teams, understanding the interdependencies of the work streams in the programs, breaking the merger down into manageable packages of work, co-ordinating their effort to ensure most efficient and effective use of the minimal time available.

Other challenges included gaining commitment at all levels within both organisations, overcoming fears of job loss and cultural fit, so that cross-functional skills and expertise would be fully utilised in delivering this time-bound, high profile initiative.

The implementation of Version 2 of the Facilitative Project Management Model for Integrated Change Implementation aided the delivery of a complex merger within the imposed deadline (the advent of the new capital gains tax legislation). The facilitative approach actively promoted the development of high-performing teams, who were committed to the venture, and worked together in an atmosphere of co-operation and trust.

The facilitative techniques guided the teams to finding their own solutions by promoting active listening, objectivity, open communication and participation. Acting as a neutral sounding board supported this, as did the asking of open, thought 

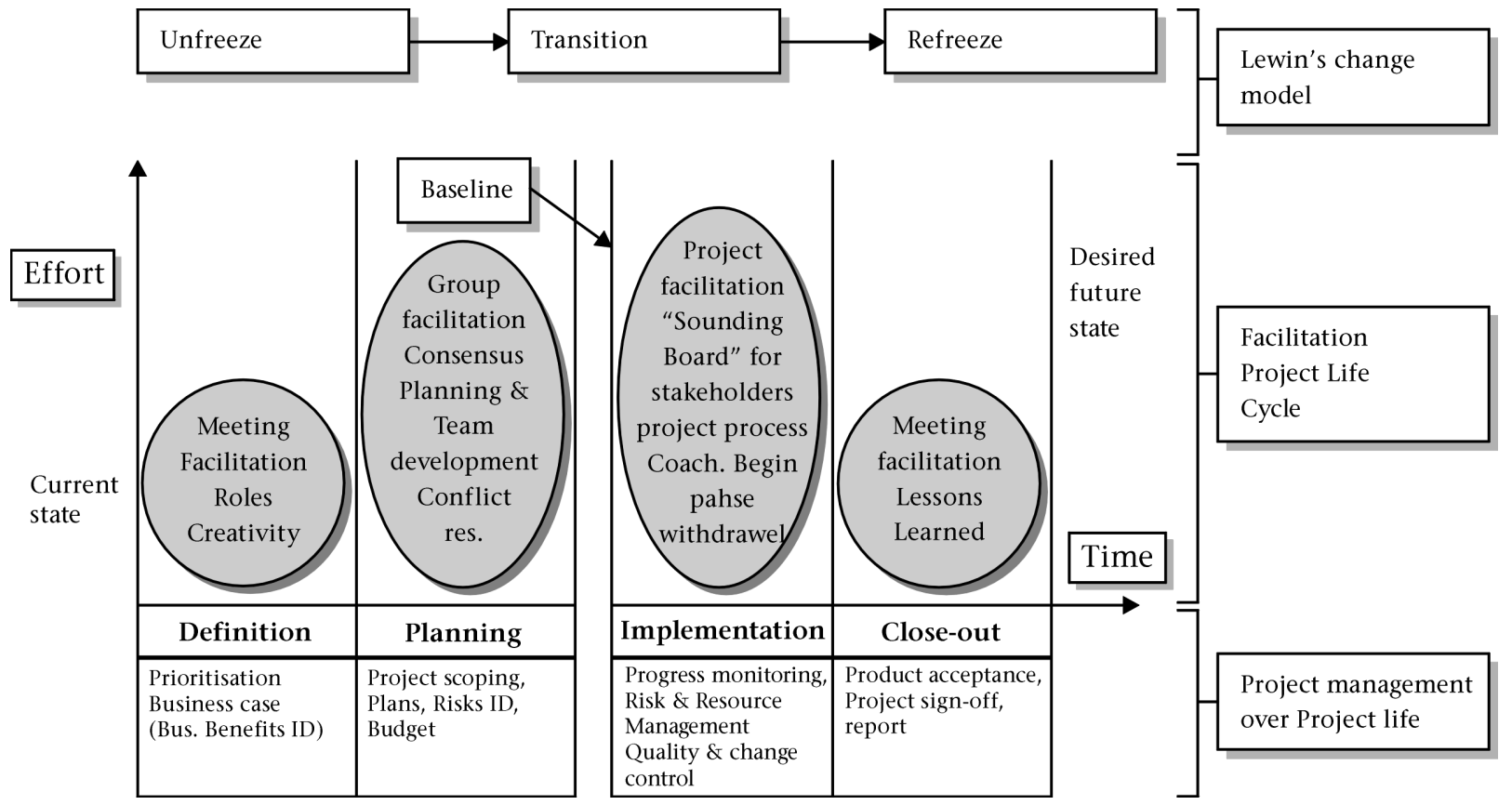

Figure 6: Facilitative project management model version 2: Integrating facilitation skills with project management phases to combine systematic and interactive aspects of change

provoking questions. This non-judgemental approach, combined with the disciplines of project management, allowed teams to take on and understand how to manage the merger process within a short time. As planned, the reliance on the facilitator decreased markedly over the project as the teams matured as demonstrated in the case study.

It became clear that planning, structure, commitment, belief and honest communication could work together to achieve full cultural integration, aid human transition, and ensure efficient merging of processes and systems.

The outcomes of the study showed that the Facilitative Project Management Model for Integrated Change Implementation was an appropriate approach. Its integrated yet generic content enabled the development of close co-operation and coordination across operational disciplines, departments, branches and organisations, which were critical to the successful delivery of a complex, high profile merger. That the merger became a positive event was reflected by the collaborative working styles, which developed, the continued retention of staff, and the flourishing of a new merged culture, which had developed initially within the program team.

\section{CONCLUSIONS}

The objectives of the research were met, in that

- The challenges faced by organisations in integrating the "systematic" business aspects (such as system design) and the "interactive" or people aspects (such as empowerment, buyin) of change management, were captured. The "typical" experience of change was documented in case study 1 , where no change management methodology was employed.

- The Facilitative Project Management Model was developed and tested within subsequent case studies, and was found to have aided the planning and implementation of change.

The essence of good change implementation is the ability to facilitate full participation in conceptualising and planning the work of the change as a series of inter-dependent projects. Risks need to be identified and action plans agreed, and a discipline of regular meeting updates within a structured meeting framework implemented. The key is obtaining consensus and commitment on all of these matters. Obtaining this requires the creation of psychologically safe environment in which to do so, where debate and opinion can be freely expressed and is not hindered by company structure and seniority. The use of facilitative techniques which encourage group discussion and contributions from less senior or the quieter members of the team, supports this.

The techniques used in the model are generic and may be explored in associations such as the International Association of Facilitators. The techniques range from those, which invite anonymous contributions to those, which encourage open forum debate, and can be chosen according to the type of culture that prevails in the organisation. An organisation has the option retaining a professional facilitator for the first such change effort, or using a person from within who demonstrates facilitative leadership skills and is seen to have the confidence of staff at all levels. It is important though, that this person be a guardian of the process of the work, and not partake in content decisions or be responsible for doing content work. This would hamper their ability to be neutral, and their availability to play the part of the neutral sounding board or pay attention to keeping the process on track.

Project management techniques are designed to be adaptable to unanticipated changes, which impact on the work of the project, and to respond in a calculated yet efficient manner. These methods are readily available (PRINCE2, Davis and Dean, X-Pert Managing by Project) and can be taught to whoever is to be leading the project teams.

Based on the outcomes of case studies 2 and 3, we believe that the critical interactive or human aspect of change can be fully integrated with the systematic or business aspect of change, in a practical way, which is easily assimilated by those within the organisation. The model cuts across disciplines and departments, enabling the co-ordination and communication so essential for overcoming resistance and achieving a seamless transition from the old to the new. Its concepts and methods embed easily within the organisation and prepares the company to meet the ongoing change challenges posed by the dynamic business conditions that rule in South Africa today. 


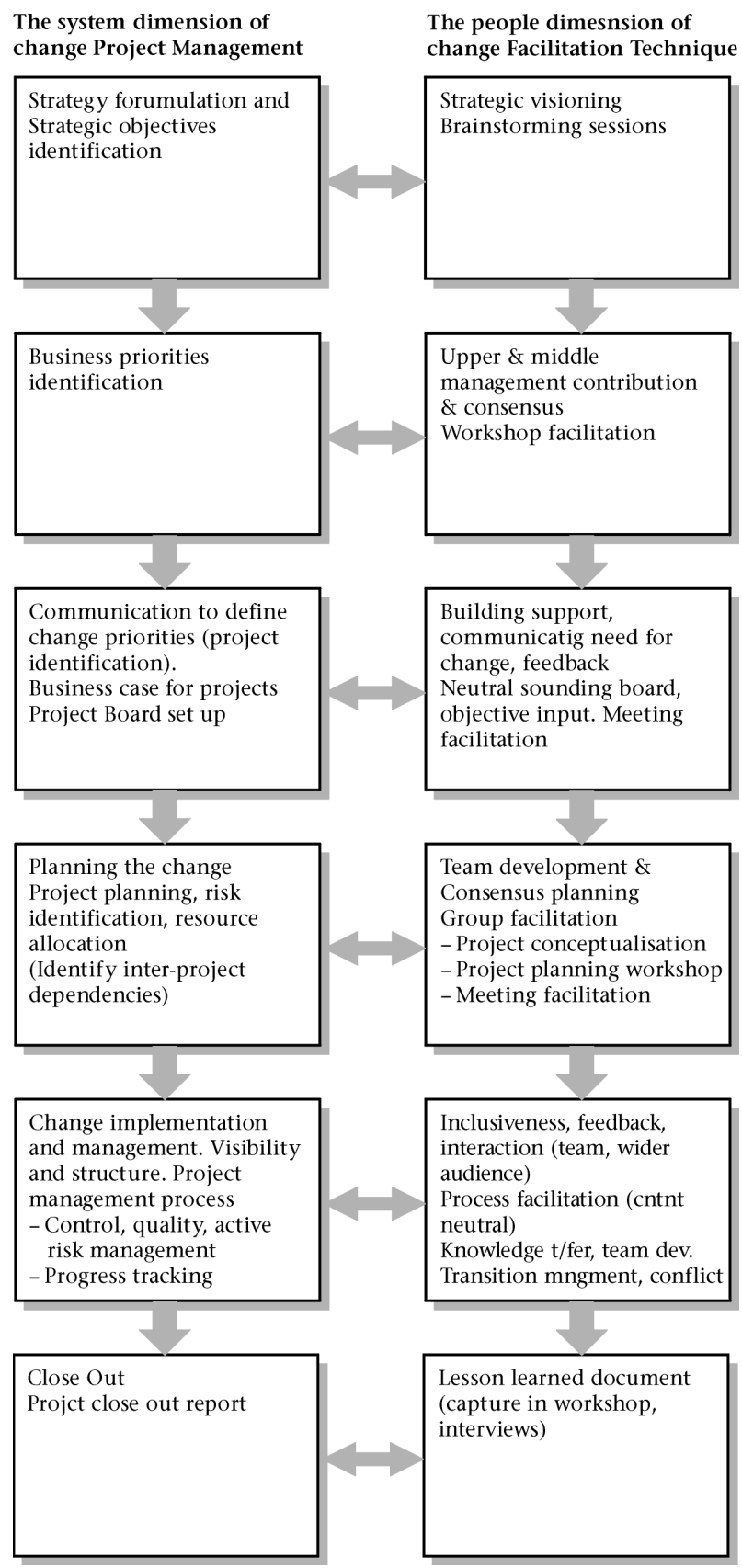

Figure 7: The facilitative project management model for integrated change implementation version 2 Tactical procedures

\section{REFERENCE}

Adams, G. \& Schvaneveldt, J. (1991) Understanding Research Methods ( $2^{\text {nd }}$ Ed.) New York: Longman.

Altrichter, H., Kemmis, S., McTaggart, R., Zuber-Skerritt, O. The Concept of Action Research, The Learning Organisation, Volume 9, Number 3, 2002, pp. 125-131, MCB University Press, ISSN 0969-6474.

Ansoff, H.I. \& McDowell, E.J. (1990), Implanting Strategic Management. (2nd Ed.) U.S.A: Prentice Hall.

Appelbaum, S.; Gandell, J.; Shapiro, B.; Belisle, P.; Hoeven, E. Anatomy of a merger: behaviours or organisational factors and processes throughout the pre-during- and post-stages (part 2), Management Decision, 38/10, (2000), 674-684, MCB University Press (ISSN0025-1747), 2000.

Ashkenas, R.N. \& Francis, S.C. Integration Managers: Special Leaders for Special Times. Harvard Business Review, November-December 2000
Bacal, R. Role of the Facilitator. Facilitation News, International Association of Facilitators, 1998.

Barrezeele, K. Seventy Percent of projects fail to be delivered successfully. De Finacieel-Economische Tijd (Belgium), translated version, 31 March 2000.

Bernick, C.L. (2001) When your culture needs a makeover. Harvard Business Review June 2001.

Central Computers \& Telecommunications Agency (CCTA) (2000), Managing Successful Projects with Prince 2 The Stationery Office. UK.

Charan, R. Conquering a Culture of Indecision. Harvard Business Review, April 2001.

Chawla, S. \& Renesch, J. (1995), Learning Organisations, Developing Cultures for Tomorrow's Workplace U.S.A., Productivity Press.

David, F.R. (1997), Concepts of Strategic Management. (6 $6^{\text {th }}$ ed.) U.S.A., Prentice Hall.

Deal, T. \& Kennedy, A. (2000), The new corporate cultures. London: Texere Publishing Ltd.

Duck, J.D. (1993), Managing Change: The Art of Rebalancing. Harvard Business Review, November-December 1993.

Epps, J. Facilitation from the Inside Out. Facilitation News, International Association of Facilitators, 1998.

Ettlie, J.E. \& O'Keefe. Innovative Attitudes, Values and Intentions in Organisations. Journal of Management Studies, 19, 1982, 2 , 163-182.

Gibbons, M., Limoges, C., Nowotny, H., Schwartzman, S. Scott, P. \& Trow, M. (1994), The new production of knowledge: The dynamics of science and research in contemporary societies. London: Sage.

Goss, T.; Pascale, R. \& Athos, A. (1993), The Reinvention Roller Coast: Risking the Present for a Powerful Future. Harvard Business Review, November-December 1993.

Grey, Denham (2001), Collaboration and Community. Smith Weaver, Smith Inc.

Hamel, G. \& Prahalad, C. (1996), Competing for the Future U.S.A. Harvard Business School Press.

Hannagan,T. (1995), Management Concepts and Practices. London, Pitman Publishing.

HST Group, Facilitating Participation: A Skills Development Program. Facilitation Concepts. www.facilitationfactory.com.

Hudson, K.M. (2001), Transforming a conservative company - one laugh at a time. Harvard Business Review, July-August 2001.

International Association for Facilitators (undated), Group Facilitation: A Research and Applications Journal - Call for Papers. International Association for Facilitators. www.iafworld.org.

in't Veld, C. (2000), Turning Point. QS Partners in Publishing, South Africa.

Johnson, G. \& Scholes, K. (1997) Exploring Corporate Strategy. $4^{\text {th }}$ Ed. London, Prentice Hall.

Kaner, S. Lind, L., Toldi, C., Fisk, S. \& Berger, D. (1996) Facilitator's Guide to Participatory Decision-making. Canada: New Society Publishers.

Kanter, R.M. (1983), The Change Masters, U.K. Unwin Paperbacks

Kotter, J.P. (1996) Leading Change USA. Harvard Business School Press.

Kotter, J.P. \& Cohen, D.S. (2002), The Heart of Change U.S.A. Harvard Business School Press.

Levy, P.F. (2001), When Good Teams Go Wrong - The Nut Island Effect. Harvard Business Review, April 2001.

Macri, D.M.; Tagliaventi, M.R. \& Bertolotti, F. (2000), A grounded theory for resistance to change in a small organisation. Journal of Organisational Change Management, Volume 15 Number 3, 2002 pp. 292-310. MCB University Press ISSN 0953-4814. [http://zerlina.emeraldinsight.com].

Mintzberg, H., Ahlstrand, B., Lampel, J. (1998) Strategy Safari The Complete Guide Through The Wilds of Strategic Management U.K. Prentice Hall.

Mouton, J. (2001), How to Succeed in your Masters or Doctoral Studies. Van Schaik, SA.

Munck, B.(2001), Changing a culture of face time. Harvard Business Review, November 2001. 
Newman, K.L. (1998), Leading radical change in transition economies. Leadership and Organisation Development Journal, 19/6 [1998], 308-324. MCB University Press. ISSN 0143-7739. [http://zerlina.emeraldinsight.com].

Oppenheim, A.N. (1992), Questionnaire Design, Interviewing and Attitude Measurement London, Continuum.

Oxford English Dictionary $5^{\text {th }}$ Ed. (1999) U.S.A., Oxford University Press.

Peters, T (1990), Thriving on Chaos U.K. Billing and Sons.

Porter, M.E. (1990), The Competitive Advantage of Nations. U.S.A., The Free Press.

PMI Standards Committee (1996), A Guide to the Project Management Body of Knowledge U.S.A. Project Management Institute.

Price Waterhouse Change Integration Team (1996), The Paradox Principles U.S.A. Urwin.

Prosci Research Staff, The ADKAR model for change management Change Management Tutorial Series. BPR On-line learning Centre, June 2000 http://www.prosci.com/adkar-overview.htm.

Robbins (1997), Managing Today U.S.A., Prentice-Hall, Inc.

Rough, J., Dynamic Facilitation and the Magic of Self-Organizing Change. Journal paper, Association for Quality and Participation Journal, June 1997.

Saunders, M., Lewis, P. \& Thornhill, A. (1997), Research Methods for Business Students. London: Pitman Publishing.

Schalk, R., Campbell, J.W., \& Freeze, C. (1998), Change and employee behaviour. Leadership and Organisation Development Journal, 19/3 [1998], 157-163. MCB University Press. [ISSN 0143-7739].

Senge, P., Roberts, D., Ross, R., Smith, B. Roth, G. \& Kleiner, A. (1999), The Dance of Change. U.K., Nicholas Brealey Publishing Ltd.
Stake, R.E. (1995), The Art of Case Study Research USA. Sage Publications.

Stanfield, B., Magic of the Facilitator. Facilitation News, International Association of Facilitators, 2001.

Strebel, P. (1996), Why Do Employees Resist Change? Harvard Business Review, May-June, 1996.

Steiner, C. (2001), A role for individuality and mystery in "managing" change. Journal of Organizational Change Management, Volume 14, Number 2, 2001 pp. 150-167 [http://zerlina.emeraldinsight.com].

Sull, D.N. (1999), Why Good Companies Go Bad. Harvard Business Review, July-August 1999.

Tracey, W.R. (1994), Human Resources Management and Development Handbook. $2^{\text {nd }}$ Ed. U.S.A.: Amacom.

Tellis, W. (1997), Introduction to Case Study. The Qualitative Report, Volume 3, Number 2, July 1997, [http://www.nova.edu/sss/QR/QR3-2/tellis1.html).

Thompson, J.L. (1997), Strategic Management: Awareness and Change, $3^{\text {rd }}$ Ed. U.K., Prentice Hall.

Torrington, D. \& Hall, L. (1995), Personnel Management, HRM in Action, $3^{\text {rd }}$ Ed. U.K. Prentice Hall.

Verma, V.K. (1997), The Human Aspects of Project Management Volume 3: Managing the Project Team U.S.A. Project Management Institute.

Watson, T.J. (1996), Motivation: that's Maslow, isn't it? Management Learning, Volume 27, Number 4, Pages 447464. London: Sage Publications.

Whitmore, J. (1994), Coaching for Performance. Nicholas Brealey Publishing Limited, London.

Woodward, H. \& Buchholz, S (1987), Aftershock: Helping People Through Corporate Change, USA, John Wiley $\&$ Sons. 